\title{
Educating Men-and-Women-for-Others: Jesuit and International Educational Identity Formation in Conversation
}

\author{
Christopher Hrynkow
}

\begin{abstract}
In a globalising world that often appears overrun by corporate and consumerist values, international education can be tempted to follow suit and support elitist transnational learning. Such an outcome may emerge intentionally or through an unreflective embrace of an unjust status quo. It follows that students and alumni of international education institutions may have little concern for more broadly communitarian values such as social justice, solidarity, and active care for those on the margins of local and global societies. However, for those craving alternatives that counteract segmented interests, this article demonstrates one such alternative. It maps how 'men-and-women-for-others,' a concept with worldwide traction in Jesuit education, can both inform and learn from international education concepts and practices. Further, this article employs the case of two remarkable Jesuit nativity schools to ground that dialogical process of meaning making, as menand-women-for-others interacts with the International Education Studies literature in a mutually enhancing manner. The results will be of interest to those committed to fostering social justice, solidarity-based action, and a glocal ethic of care amongst the students and alumni of both Jesuit and international educational institutions.
\end{abstract}

KEYWORDS Jesuit education, international education, men-and-women-for-others, social justice, Pedro Arrupe, nativity schools

Jesuits are members of the all-male Roman Catholic religious order, the Society of Jesus. In 1973, their Superior General, Pedro Arrupe, delivered an address to an international group of Jesuit Alumni in Valencia, Spain. In that speech, he called on Jesuit educational institutions around the world to work to ensure all their students and graduates act as 'men for others'. That day, Arrupe offered a vision of what the resultant ethic of community engagement would entail in terms of education for social justice and social action. More recently, this call often proceeds with the framing of 'men-and-women-for-others,' in order to reflect more adequately the composition of the student bodies and alumni of contemporary Jesuit educational institutions. The present article will proceed in dialogue with international education concepts and practices. It will source these concepts in the International Education Studies literature. However, it will also draw out treatments of international education concepts and practices as articulated, often for different purposes and with divergent framings, from Jesuit sources, 
along with perspectives on international issues from other disciplines. Here, it is important to emphasize that 'Jesuit' when used as descriptor in this article invokes a broad sense of the term to denote a worldview inspired by the Jesuits' integrated approaches to learning and their distinctive spiritual practice, which, as expressed in school, college, university contexts focuses on education for the whole person.

Though only focussing on education for justice, which is but one part of the integral Jesuit worldview, bringing such a perspective into conversation with community-engaged scholarship will also allow this article to make a modest contribution on the data normally considered by those addressing the subject matter of international education concepts and practices. Such a conversation will serve to benefit both Jesuit and international perspectives on studying and participating in the educational project in dialogical manner (i.e., fashioning a positive feedback loop). Through that dialogical approach, this article will explore how Arrupe's call has been brought forward in contemporary articulations of Jesuit education, with a particular focus on its ethical implications in a globalising world, and with reference to the two Canadian nativity schools, which were recently constituted with a goal of fostering deep equality. Select insights emerging from this dialogical mapping process will be highlighted below for their potential to inform values-based international education geared towards fostering social justice, solidaritybased action, and a glocal ethic of care (i.e., combining international and local concerns, cf. Vallaeys, 2014 on universities' social responsibility). In this manner, the present article will move from providing a survey of the relevant contexts and theoretical reflections to the rendering of two case studies and an analytical synthesis.

\section{A Particular Type of Identity Formation}

One place begin to see the resonance of this article's titular term amongst alumni of Jesuit schools is in the lead story in the sports section of the Winnipeg Free Press on January 30, 2016:

Mark Chipman went to St. Paul's High School. So did I.

He turned out a little more successful than I did. But what we both had drummed into us by the Jesuits all through high school that our purpose on this planet is to be a "man for others".

It's a simple Jesuit idea: the meaning of life is a life with meaning, and the route to finding that meaning is to be of service to those around you.

Again, Chipman embraced this concept a little more fully than I did.

I cut my neighbour's lawn; Chipman is rebuilding Winnipeg's downtown, one block at a time.

But what happens when a "man for others" finds himself owning a team in a league in which all the players are in it for themselves? (Wiecek, 2016, p. C1).

While the newspaper feature proceeds to discuss about National Hockey League team ownership in a small market, it introduces a derivate of the central concept of this article and the standing of that model in contemporary Jesuit education. This article returns to a discussion of the person of Chipman below, but first it is important to explore how men-and- 
women-for-others is a much thicker concept than is implied in these few lines.

Jesuits concentrate upon identity cultivation, both in terms of their extensive formation process and their related work as instructors of school, college, and university students. The term 'Jesuit education' is, however, more expansive, including not only members of the order but also indicating how lay people now participate in the mission of Jesuit educational institutions as instructors, administrators, and visionaries. The holistic spirituality related to this endeavour often earns the title 'Ignatian', flowing from the name of the order's founder, Ignatius of Loyola. As will be unfolded below, Jesuit education supports an internationalising project in a non-statist sense. This support is the origin of the pairing of Jesuit education and other solidarity-oriented form of international education with 'glocal ethics' in this article. As will become evident, the full meaning of global ethics invoked below includes this 'glocal' variety, which places the local and the global in relationship and hence counts local, national, international, and transnational concerns as integral to any full global consciousness. Invoking such dynamics, this article demonstrates that Jesuit education, when fostering identify formation around 'men-and-women-for-others', represents a confluence working towards the incarnation of principles associated with glocal ethics, that is, morality that holds in creative tension global, internationalist, and local ethics (Cf. Urkudi, 2010).

This article's central term and its derivatives are phrases that grow out of Arrupe's aforementioned 1973 address on education for social justice and social action. Those imperatives relate well to the 'see, judge, act' methodology, which underpins praxis as it informs expressions of Catholic identity that are both socially engaged and internationalist (Cf. Barre, 2001; Alonso, 1961; Segundo, 1976). It also receives support from the Catholic Social Teaching tradition, notably in John XXIII's encyclical Mater et Magistra, which upholds the spirit of 'see, judge, act' processes as a method for reading and responding in a practical manner to the signs of the times: "It is important for our young people to grasp this method and to practice it. Knowledge acquired in this way does not remain merely abstract, but is seen as something that must be translated into action" (John XXIII, \#237; cf. Ochocka \& Janzen, 2014).

Mater et Magistra can be read here as an international education document in a broad sense, encouraging interaction with both local and global contexts. Hence, the document can be shaded as naming an imperative for Catholic education to cultivate glocal consciousness, which is community-engaged in both a transnational and local sense. Such papal invocations as the one found in John XXIII's social encyclical are important in the context of Catholic education and have an international reach into multiple contexts worldwide. The Jesuits have a parallel reach across the globe. In the case of a men-and-women-for-others framing, the assumed outcome of such community-engaged interaction with diverse contexts is a multifaceted, relational altruism.

Prior to Arrupe's first articulation of the men-and-women-for-others concept, Ronald Modras (2004) imagines the Superior General applying the basic Jesuit rubric of examination of conscience to the Society of Jesus as a whole. A particular point of reflection was the Synod of Bishops' (1971) statement: "Action on behalf of justice and participation in the 
transformation of the world fully appears to us as a constitutive dimension of the preaching of the Gospel" (\#6). Given the centrality of the Gospel to Christian living in the world, such an examination of conscience supports the conclusion that social justice is also essential to the life of the Roman Catholic Church and its religious orders. As such, men-and-women-forothers can be understood as one significant implementation of John XXIII's formulation of 'see, judge, act' methodology in Jesuit education.

An important goal of this article will be to map instances of the impact of a men-andwomen-for others framing as expressed through the type of values extolled by Jesuit schools, colleges, and universities, particularly in terms of the qualities they aspire to see incarnated in their students and alumni, and then to bring that mapping into conversation with international education concepts and practices. As one result of this approach, the present article will be international in terms of the (1) location of educational institutions discussed, (2) the origins of policies, practices, and principles mapped, and (3) articulating the significance of 'men-andwomen-for-others' for mainstream international education theory and practice.

\section{Jesuit Education in an International Perspective}

Jesuit education and international education are two idea-driven fields oriented towards practice with a great more deal in common than might be expected. Jesuit identity has a tendency to be cosmopolitan, communitarian, internationally minded, and oriented towards inter-cultural understanding. For example, Canadian Jesuits International (2016), drawing on the talents of both members of the order and lay people, focuses a large percentage of its work on educational projects and other sustainable development initiatives to overcome global inequality (cf. Hall, Escrigas, Tandon \& Granados Sanchez, 2014). This internationalist orientation transfers to the order's selection of full members (they will not allow individuals who do not embody core Jesuit values to continue in the order). Additionally, as mentioned above, this orientation transfers into Jesuit educational efforts to which, it is important to emphasize, the adjectives 'Jesuit' or 'Ignatian' now frequently apply even as they extend to lay students, staff and, in the contemporary era, to teaching faculty who are not members of the order.

Tapping into these dynamics, there is both a transnational and local dimension to Jesuit education. These dimensions are cultivated through professional development initiatives, inter-institutional workshops, formative retreats, and other training events. This programming can extend to the appointment of dedicated staff, such as identity and mission officers in the USA, who work to foster Jesuit principles within their institutional communities. As a result, Jesuit education is a global effort; presently, there are close to 700 Jesuit or 'Ignatian' schools, colleges, and universities located in over 65 countries around the world (for an interactive global map plotting these institutions, see Educate Magis Staff, 2016).

Moreover, educational networks associated with the schools and other Jesuit networks are involved in transnational partnerships with what Joseph M. O'Keefe (2011) expresses as a goal of fostering "a more humane, just, and sustainable global society" (p. 336). The relationship with context, both local and global, is key here and is summarised by Kavanaugh (1989): 
"Jesuit education if it is to be real will both influence and be influenced by the socio-political order and the lived concrete praxis of the persons educated and educating" (p. 168).

Men-and-women-for-others can be read as an expression of this Jesuit worldview. Noteworthy in this regard is the concept's orientation towards reflectively fostering a particular type of morally-infused identity that, in accord with International Education Studies theorist Richard Bates' (2012) view that citizenship needs to move beyond narrow associations with specific nation-states, is at once transnational but grounded in place via concern for both local and global justice. In order to begin to understand such connections and their roots in the order, it is necessary to briefly survey Jesuit history as it relates to education, and, in particular, to international education concepts and practices.

In 1534, an international group of students nearing the end of their studies in a transnational context at the University of Paris formed what was to become the Society of Jesus (O'Malley, 1993). The Jesuits remain an international order. Further, because its members are not bound to dioceses, to a certain extent the Society of Jesus transcends nationalist socio-geography. Influenced by Renaissance humanism, their formation was within a context international education in a pre-modern global system (cf. Therborn, 2000) during a time of religious upheaval in Europe and European expansion into the New World (see Modras, 2004), which was in part fueled by a desire to 'win' souls, that, in turn, resulted in violent evangelism (see, for example, Christensen, 2013).

Eight years after the order's approval, the Jesuits founded their first school at Messina in 1547-1548 (Padberg, 1991). The curriculum at Messina was a response to the state of formal schooling in Europe. At that time and sharing some resonance with the justification for international schools today (cf. The Economist Staff, 2014), the educational system was deemed poor or inappropriate to meeting local demands for skills and knowledge in relation to the then contemporary globalising reality (cf., Brown, Lauder \& Aston, 2010). From this situation today, as in the Catholic Reformation period, flows the perceived need for an alternative.

Within a generation of their formation, the Jesuits also established a school at Macao in 1585 (O'Malley, 2000). As part of the then current wave of globalisation (cf. Therborn, 2000), Macao was a colony of Portugal, ruled by a prominent monarch of the Catholic Reformation, Phillip II of Spain. In general, King Phillip was keen to employ the Jesuits in his empire-building projects (see Parker, 1998). In another parallel to contemporary international schools, the Jesuit school at Macao had a trans-border character, inclusive of a student body consisting of expatriates and the children of local elites. Indeed, by this time across Europe, a critique of elitism had already formed against the Society of Jesus (O’Malley, 2000). Elite and upwardly mobile parents were attracted to Jesuits schools and colleges in places like the Italian peninsula, where the established universities fees. In contrast, the Jesuits provided an education, one understood as appropriate for the emerging challenges of the global system, at no charge (see Consolmagno, 2014). Hence, it was sometimes difficult for the Jesuits to keep up with demand for their services, balancing the teaching of a reinvigorated Christian humanism and meeting the more pragmatic educational needs of the day (Ganns, 1956). In line with contemporary international schools of the sort who like to ensure quality in teaching and 
enjoy being oversubscribed (see Boland, 2011), the order insisted its educational institutions be well-endowed and not just opened or unduly expanded to fill the obvious demand (Scalglione, 1986). Although the time of standardised curriculum for all Jesuit educational institutions is now past, core features of Jesuit education remain. These features are reinforced by regular lateral correspondence between Jesuit institutions (a tradition dating to back to St. Ignatius [Padberg, 1991]), international meetings (notably, General Congregations, of which there have been 36), and transnational issue-based organisations that pervade the Ignatian universe. In the contemporary era, meetings between Jesuit advocacy networks serve to share insights and resources in order to live out their charism of working for justice (e.g., Garcia \& Sendin, 2015).

It was in this spirit of amplifying the order's charism for justice that Pedro Arrupe delivered his landmark speech. In addition to the aforementioned influence of the 1971 Synod of Bishops, which he attended, Arrupe was motivated to promote an option for social justice, partly because of his international educational and formative experiences in Spain, Holland, Belgium, the USA, and Japan. In that last case, he administered to the need of victims in the immediate aftermath of the bombing of Hiroshima, having been at the Jesuit novitiate on the outskirts of the city and literally knocked over by the force of the blast after the first deployment of a nuclear weapon. Some 28 years later, the occasion for this new defining moment was the 1973 International Congress of Jesuit Alumni held in Valencia, Spain. That day started a process that included the integration of men-and-women-for-others, originally a protestant concept developed by the Lutheran theologian Dietrich Bonheoffer, into the Jesuit ethos (Modras, 2004). In summarising the magnitude of that day for Ignatian values, Paddy Walsh (2000) states that Arrupe's address, "rapidly became part of the canon of modern Jesuit thinking on education and is frequently cited in later documents" (p. 135). This process benefited from the feeling amongst many Jesuits, some of whom had heard his international lecture tour on his experience in the aftermath of the bombing of Hiroshima, that Arrupe himself was a man-for-others and could thus promote the ideal with a significant measure of integrity (cf. Madelin, 1991).

The context of the speech in Valencia may be familiar to those involved with alumni events at international schools. Perhaps a more focussed parallel would be the case of the United World Colleges (UWC) as discussed below for the way they represent a group of educational institutions joined through a common framework that is value-laden and whose alumni form sub-networks amongst themselves within a larger framework of shared identity and ideology (cf. Tsumagari, 2010). At such alumni gatherings, the imperative to raise funds to ensure the financial health of schools and the educational network is never far from the surface. Despite the risk of alienating a key constituency of transnational funders, Arrupe chose the occasion of an international gathering of Jesuit Alumni to set a prophetic challenge: Jesuit education would henceforth address what he defined as a major gap in terms of what Jesuit education ought to be. His methodology for filling that gap was through actively fostering social justice marked by community engagement. Ronald Modras (2004) sets the scene: "Arrupe knew the men seated before him were not expecting anything like this... These prosperous, well-dressed products of Jesuit schooling expected to be congratulated on their successful careers and 
commended for their loyalty to the Church and their alma maters. They had not come to be told there had been deficiencies in their Jesuit Education" (p. 243).

In his typical pastoral style, Arrupe (1973) located the lack of substantive consciousness of social justice as the major deficiency, which mandated a reorientation of Jesuit educational institutions' learning outcomes in accord with a glocal ethic of care fostered by deep, religiously inspired community engagement:

Today our prime educational objective must be to form men-and-women-for-others; men and women who will live not for themselves but for God and his Christ-for the God-man who lived and died for all the world; men and women who cannot even conceive of love of God which does not include love for the least of their neighbors; men and women completely convinced that love of God which does not issue in justice for others is a farce.

This kind of education goes directly counter to the prevailing educational trend practically everywhere in the world. We Jesuits have always been heavily committed to the educational apostolate. We still are. What, then, shall we do? Go with the current or against it? I can think of no subject more appropriate than this for the [Superior] General of the Jesuits to take up with the former students of Jesuits schools.

The danger implied here is that knowledge production at Jesuit schools, colleges, and universities and the graduates of those institutions themselves will merely reproduce an unjust status quo (cf. Gaventa, 1993). Arrupe was prescriptive in terms of how to address the resultant gap between Gospel values centred on justice and the lived reality of too many people that is often marked by oppression and marginalisation. Addressing the gathered alumni directly, he further presented that ethical gap as leaving Jesuit education wanting when judged against a yardstick of contemporary Catholic Social Teaching:

Let me ask this question: Have we Jesuits educated you for justice? You and I know what many of your Jesuit teachers will answer to that question. They will answer, in all sincerity and humility: No, we have not. If the terms 'justice' and 'education for justice' carry all the depth of meaning which the Church gives them today, we have not educated you for justice.

What is more, I think you will agree with this self-evaluation, and with the same sincerity and humility acknowledge that you have not been trained for the kind of action for justice and witness to justice which the Church now demands of us. What does this mean? It means that we have work ahead of us. We must help each other to repair this lack in us, and above all make sure that in future the education imparted in Jesuit schools will be equal to the demands of justice in the world.

Arrupe (1973) went on to decry not only personal sin that treats people as mere instruments, but also social sin that creates a system of domination, which negatively affects both persons and nations (cf. Sobrino, 1991). Additionally, he called for deep personal conversion and structural transformation in order to humanize all moral associations and achieve a more just world (cf. 
Vallaeys, 2014). As a result, men-and-women-for-others represents a sort of shorthand for the type of person who positively participates in the transformation of the world within this rubric of "Earthy liberation" (Arrupe, 1973; cf. Hall, Escrigas, Tandon \& Granados Sanchez, 2014). The superior general mandated that all Jesuit educational efforts around the world must commit to this set of goals. Indeed, for Arrupe (1973), this transformative commitment was absolutely essential for forming human agents in the face of a globalising reality, a point he makes with reference to a key text penned by the Society of Jesus' founder: "Men-and-womenfor-others: the paramount objective of Jesuit education-basic, advanced, and continuing-must now be to form such men and women. For if there is any substance in our reflections, then this is the prolongation into the modern world of our humanist tradition as derived from the Spiritual Exercises of Saint Ignatius. Only by being a man-or-woman-for-others does one become fully human".

An important confluence is present in these moral sentiments between (1) the concept of "international-mindedness", a state of cross-contextual awareness, framed as an antidote to segmented interest from the International Education Studies literature (cf. Hill, 2012), and (2) the justice-infused Jesuit values that both students and alumni are meant to take into the world with them. Here, there is a slight contrast with the youthful location of 'see, judge, act' as articulated by John XXIII (1961). In regards to identity formed through community engagement, a parallel with men-and-women-for-others as an educational outcome on the level of identity is evident with the International Baccalaureate (IB) learner profile. That profile, of the characteristics an IB student should come to embody, includes a measure of global ethical content. Similarly infused with values that, as per the case of Jesuit education, if incarnated, would serve as an antidote to segmented interests, the IB Profile describes learners who are "inquirers, knowledgeable, thinkers, communicators, principled, open-minded, caring, risk-takers, balanced, and reflective" (IBO, 2013).

An area of divergence here is that men-and-women-for-others acts as catchall, summarising and pointing back to a whole host of Jesuit values in a way that is relatively more communitarian than the more individualistic IB learner profile. Such 'profiling' of characteristics of IB school alumni ought to incarnate also points back to values-based commitments referenced in the International Education Studies literature (see Hill, 2012). Despite its promise, this learner profile seems more easily co-opted into an agenda for globalising business as evidenced by the authorised adoption of the IB Diploma Program by for-profit international schools, including ones within major transnational networks (cf. Bunnell, 2000). A notable example is Global Education Management Systems, owned by the Dubai-based entrepreneur Sunny Varkey, which runs 88 for profit international schools in 13 countries. This corporation also invokes core values as one of the reasons for its success (see GEMS staff, 2016). However, its corporate structure and ethos retain much of individual self-interest driving an international network of schools and colleges with a limited moral compass. Herein, education, inclusive of the articulation of values becomes a commodity and profit-oriented success for both owner and customers (i.e. parents and students) is what is on offer. As a result, self-referential globalised business norms take on a more significant role than altruistic internationalism also. 
For contemporary Jesuit education, the self is also certainly important, as evidenced in the associated methodology of examination of conscience and other practices, some of which are related to the aforementioned 'see, judge, act' approach concerning the necessity of personal reflection. Nonetheless, in contrast to an atomistic-individualist perspective and flowing from the general orientation of Ignatian spiritually to see God as present in (and, therefore, binding together) all things (see Ignatius of Loyola, 1991), it is almost invariably understood as a selfin-relationships (cf. Bai, Cohen \& Rabi, 2014). Hence, the Society of Jesus' emphasis on both (1) obedience within the order (see Perry's [2015] proposal that this is the true Jesuit charism) and (2) efforts to incarnate social and ecological justice in the world based upon being a 'contemplative in action' (see Barry \& Doherty, 2002).

A common focus here is on integral identity formation of the sort that recalls Kubow, Grossman, and Ninomiya's (2000) articulation of a goal for international education of helping to establish multidimensional citizenship in the 21 st century. Both strains of identity formation draw upon personal, social, spatial, and temporal dimensions, and are inclusive of systematic critical thinking, an embrace of service learning, and a willingness to engage in social and public life at the local, national, and international levels. In considering such parallel commitments, a cogent conversation partner for Jesuit education in terms of an international education network is UWC (United World Colleges).

Founded in 1962, UWC (2016) is a network of 17 schools, with national committees in over 150 countries. UWC take as foundational strong commitments to human rights and other internationalist programming associated with the best features of organisations like the United Nations, including an emphasis on the importance of students and teachers from diverse national backgrounds interacting and learning with each other. UWC schools often offer IB programming. In that light and as opposed to institutions oriented towards a globalising business agenda, UWC mission and values statement can be read as a way to articulate the IB learner profile in a more communitarian direction, recalling Mestenhauser's (2002) point that internationalising education has to be about more than preparing students for careers. For example, UWC (2016) group of international schools' mission statement emphasizes a commitment to "make education a force to unite people, nations and cultures for peace and a sustainable future". UWC (2016) also lists a number of related values they promote as part of their contribution to international education (cf. Cambridge \& Thompson, 2004).

\section{Men-and-Women-For-Others and Jesuit Education}

Like the UWC group example, Jesuit schools invoke values as part of their formative ethos. Go Forth and Teach: The Characteristics of Jesuit Education, unambiguously states that in a Jesuit school: "Justice issues are treated in the curriculum" (ICAJE, 1987, \#78. All emphasises in the citation of this document are in the original). In accord with Phillips and Schweisfurth's (2008) reflections on global citizenship education and its close association with international education, this priority can be read as supporting a global ethical consciousness as integral to the aforementioned education of the whole person: 
For 450 years, Jesuit education has sought to educate "the whole person" intellectually and professionally, psychologically, morally, and spiritually. But in the emerging global reality, with its great possibilities and deep contradictions, the whole person is different from the whole person of the Counter-Reformation, the Industrial Revolution, or the twentieth century. Tomorrow's "whole person" cannot be whole without an educated awareness of society and culture with which to contribute socially, generously, in the real world. Tomorrow's whole person must have, in brief, a well-educated solidarity. We must therefore raise our Jesuit educational standard to "educate the whole person of solidarity for the real world" (Kolvenbach, 2008, p. 155).

In a point recognised by publicly accessible codes of conduct for faculty at international educational institutions (e.g., CIS, 2015), crucial here is that teachers and professors embody these values. To this end, the Society of Jesus' norms mandate that: “The adult members of the educational community - especially those in daily contact with students - manifest in their lives concern for others and esteem for human dignity" (ICAJE, 1987, \#84). As also active in a number of international schools (e.g., Gerlicz and Stavarz, 2011), Community Service Learning (CSL) is another expression of the desired character outcome for students and alumni of Jesuit educational institutions. CSL is in accord with "a community-based research approach recognizes the community as knowledge-rich partners and does not portray knowledge as the some domain of academic institutions" (Ochochka \& Janzen, 2014, p. 18). Further, a central concept of Jesuit education, connected to the promotion of social justice through community engagement, is committed to learn "through contact not concepts" (Kolvenbach, 2008, p. 155). Although, given the Jesuit focus on educating the whole person in all their physical and spiritual dimensions, although certainly not the only factor in play, a telling link here is with the notion that international mindedness is 'caught' and not solely formally taught (cf. Thompson, 1998). Further, such a synthesis accords well with desired ethical outcomes of experiential learning for community engagement, signified when the vision invoked by 'men-and-womenfor-others' is incarnated through CSL work. In this light, consider Ian Hill's (2012) assertion that international mindedness is more about what is done within an educational institution rather than the demographics of the learning community. Charles Gellar's (1993) adds that any school around the world, public or private, holds the potential to be international. Lending further support to Hill's observation, Gellar continues that qualifying the category of 'international mindedness' is "not so much curriculum, but what takes place in the minds of children as they work and play together with children of other cultures and backgrounds. It is the child experiencing togetherness with different and unique individuals; not just toleration, but the enjoyment of differences and unique individuals" (p. 7). Jesuit educational institutions can qualify as international under this rubric, especially where not only cultural but also national, gender, and class differences are taken into account. Indeed when imagining such a situation and where the instructors, staff, and a critical mass of students model the ideal of men-and-women-for-others, it might be said that 'caught not taught' can take on qualities of a positive contagion activated through mimetic learning processes (cf. Girard, 2003) in both 
Jesuit and mainstream international education institutions.

In a general confluence with the above discussion of 'see, judge, act,' Ralph Metz (1995) characterizes the Jesuit pedagogical paradigm as "context, experience, reflection, actions and evaluation" (p. 7). Invariably, such reflection is understood as properly motivated by the aforementioned Ignatian vision of the whole person. For its part, the International Commission on the Apostolate of Jesuit Education (ICAJE), when focussing on social justice and building upon insights gained in many contexts across the globe and during a seven-year, worldwide consultative process on the characteristics of Jesuit education, asserted: "In a Jesuit School, the focus is on education for justice. Adequate knowledge joined to rigorous and critical thinking will make the commitment to work for justice in adult life more effective" (ICAJE, 1987, \#77).

In accord with University World Colleges' (2016) ideologically driven pedagogy, this educational approach is concerned with both local and global issues of justice across myriad issues and concerns. As Halstead and Taylor (2000) note, such a focus on justice can positively shift the effects of schooling on moral development. In this regard, Robert Mitchell (2008) identifies a key definitive feature of Jesuit education in "a preoccupation with questions of ethics and values for both the personal and professional lives of graduates.... [Recently] Jesuit institutions have tried to focus attention on the great questions of justice and fairness that confront our age: economic problems, racism, and unemployment in our own country; peace and war and the proliferation of arms; and poverty and oppression in the third world" (pp. 111-112). As per the UWC (2016) example cited above, this preoccupation is very active, focusing heavily on civic participation and social transformation as the telos of communityengaged learning (cf. Spilker, Nagel, Robinson, Brown \& Tremblay, 2016).

For example, Charles Bernie's (2013) monograph on the University of Central America in San Salvador (where, in 1989, six Jesuits, their housekeeper, and her daughter were martyred) characterizes its expression of Jesuit education as value-driven, purposely seeking to foster agents of social change. It is authentic to read this transformative approach as representing sought after fruit of community engagement for Ignatian praxis buttressed by an integral view of the human person (cf. Gaventa, 1993). It follows that, in agreement with Bernie's analysis and resonating with a full meaning of men-and-women-for-others as part of a survey of the value of social justice in Jesuit education, Kavanaugh (1989) asserts: "The theory and practice of justice can intensify the focus not only of an institution, but of an individual's life" (p. 175). Such a dynamic orientation towards actively working for positive social change is discernible in the example of the Society of Jesus' founder: "Ignatius asks for the total and active commitment of men and women who, to imitate and be more like Christ, will put their ideals into practice in the real world of ideas, social movements, the family, business, political and legal structures, and religious activities" (ICAJE, 1987, Appendix II). Here, Go Forth and Teach articulates the Jesuit worldview as it applies to imperative to incarnate social justice. Serving to reinforce that connection, the printed notes in margin at this point in the document reads, "Seeks to form 'men and women for others' - manifest a particular concern for the poor” (ICAJE, 1987, Appendix II). 
For his part, Nicholas Rashford (1999) situates men-and-women-for-others as part of the international dimension of Jesuit education. Consider the trans-cultural and global nature of the order as an advantage in this light: "There is an international dimension to the Jesuit tradition...that reflects both the richness and the complexity of the world that we live in. Pedro Arrupe...framed the now world-famous statement on the call for Jesuit-educated individuals to men - and we now say women - for others. We continue this tradition and realize its profound effect on Jesuit Higher Education" (p. 2). In accord with the above discussion of CSL, Charles Currie (1999) makes links amongst Jesuit education, social engagement, and activism:

\begin{abstract}
Closely related to the activity on behalf of identity and mission is the impressive record of how our...schools express the Jesuit commitment to link faith an authentic concern for justice, and to educate "men and women for others". In addition to community service opportunities, service learning — which links service activity with reflection and classroom analysis — is becoming a staple in the academic life of our schools. Local, national, and international immersion experiences in Appalachia, Mexico, and various inner cities enrich the lives of students, faculty, staff, and, in many cases, our alumni. There are important examples of faculty sharing their expertise with communities and community leaders, linking academic research with social activism. Increasingly alumni participate in these activities. This bears testimony that we are indeed graduating "men and women for others" (p. 5; cf. Spilker, Nagel, Robinson, Brown \& Tremblay, 2016).
\end{abstract}

Joseph O'Hare (1999) makes explicit the unity of this discourse, by coupling the concept of men-and-women-for-others with values-infused global citizenship education (cf. Davies, 2003): "the Ignatian contemplative who searches for God in all things must also be a contemplative in action....At a time when American educators are recognising the importance of education for citizenship and seek the elusive goal of developing character, the apostolic character of Ignatian spirituality summons us all, faculty and students, to be 'men-and-women-for-others,' and in this way redeems the university's commitment to the wider community" (p. 442; cf. Vallaeys, 2014).

This redemptive and community-oriented feature of Jesuit education is on display in the two Canadian nativity schools discussed in detail below and in the Jesuit Commons: Higher Education at the Margins (JC:HEM, 2016) project, which is a remarkable instance of international education. The latter project, run by the Jesuit Refugee Service, brings together international partners, including university faculty from around the world. Students take online courses, with no fees, from learning centres in refugee camps and rural areas. Each full module section of 15 students can be composed of people learning at up to ten of these centres. The graduates gain qualifications, such as the diploma in Liberal Arts from Regis University owned by the Society of Jesus and located in Denver, Colorado. Speaking on the occasion of a graduation ceremony at the Dzaleka Refugee camp in Malawi, Mary McFarland (2014), the JC:HEM International Director named the goal of the new alumni's learning as transformation on the personal and global levels. In this manner grounding the potential of 
bringing international and Jesuit identity formation into conversation, she explicitly emphasised that their qualification from a Jesuit university carried with it responsibilities to be men-andwomen-for-others.

\section{Tensions and Promises}

The fostering of 'global citizenship' of the type referred to by McFarland is a common theme in the International Education Studies literature (e.g., Bates, 2012). Read in light of that theme, men-and-women-for-others emerges as an instance of internationalising identity. Significantly, in the case of Jesuit Education, one can discern an identity with a strong normative orientation for social justice and community engagement (a particular kind of open/international mindedness). Here is an example of a place for dialogue, other roots of which are evident throughout this article, about how a Jesuit pedagogical approach can both inform and be informed by international education concepts and practices. It is important to consider how undertaking such a conversation can theory and praxis in both cases. For example, Jeff Thompson and Mary Hayden (2008) make links amongst shared value systems, diversity and balance as key features of international education. Considering social justice and community engagement amongst such values can be fruitful to the theoretical understanding and effectiveness of both projects as they are each read in light of the other. In this manner, several tensions and promises come into view from a perspective concerned with emancipationoriented community engagement when International Education Studies concepts, interact with Jesuit educational vision as they both relate to identity formation.

It is informative, for instance, to consider the nature of the authority that both sanctions and supports the educational vision of 'men-and-women-for-others' mapped above. In this regard, there is value of reading Arrupe's landmark speech as roughly parallel to the authority given to IB norms because of their role in certifying schools (see IBO, 2014). Notably, however, in the former case there is a potentially stronger duty and level of accountably to the Superior General and Provincials in regards to individual members of the Society of Jesus and Jesuit schools. Seen through such a comparative lens, the consequence of this situation is that there is a discernible pull towards hierarchical, rather than participatory, models of education when actually implementing men-and-women-for-others in identity formation processes. Such dynamics may be active, for example, when imposing the concept within a military framework that tends towards viewing the Society of Jesus' charism as 'obedience' as transferred not only to Jesuits, but also to lay teachers and staff, and students at Jesuit educational institutions. Moreover, there remains a tension within Jesuit schools, colleges, and universities in terms of educating student bodies composed of elites. This tension is particularly pronounced in exclusive, male-only Jesuit schools. Notwithstanding other social justice and communityengaged educational projects like the nativity schools explored below, the continued staffing and maintenance of elite educational institutions can seem juxtaposed to Arrupe's vision of fully integrating the 'preferential option for the poor'. In this regard, Jesuit education, similarly to international schools, may tend towards lending greater support for a trans-global 'Jesuiteducated old boys' culture rather than fostering the incarnation of social justice and a creative 
common good (cf. on networks, Spilker, Nagel, Robinson, Brown, \& Tremblay, 2016).

Here, it is rather haunting to read Cambridge and Thompson's (2004) frank assessment of a tension in international education and to consider whether Jesuit alumni networks are much different. During their discussion of varieties of 'international education,' which they rightly shade as an ambiguous term, Cambridge and Thompson (2004) note, "it encourages positive attitudes to community service, global citizenship and meritocratic competition whilst it is used as a means of enhancing positional competition and personal economic advancement" (p. 172). In contrast to the values of responsible citizenship and more integral moral development associated with 'internationalist' pedagogy, Cambridge and Thompson (2004) also discern another variety of international education: 'globalist.' This globalist approach serves segmented interests that tend to benefit from the current wave of globalisation (cf. Therborn, 2000). Cogently for this article, they assert, "an outcome of globalist international education is global cultural convergence towards the values of the transnational capitalist class" (Cambridge \& Thompson, 2004, p. 173).

However, in the Ignatian context, while globalist cultures still persist at Jesuit educational institutions, an antidote to transnational capitalist class production is discernible in programming like bursaries. Moreover, specially constituted schools may represent an attempt to tap into Jesuit alumni networks to broaden their composition. Bursaries, or at the very least scholarships, are often on offer at international schools. When the former are a tangible possibility for students coming from marginalised communities that opens up what may otherwise be elite institutions in a more lateral direction. However, an issue remains as to whether bursaries to attend elite educational institutions are sufficient in terms of a substantive vision for social justice and community engagement lived out on the level of identity like the one espoused by Arrupe.

In terms of a grounded methodology oriented toward deeply incarnating that vision, consider the emergence of Jesuit nativity schools working toward equality of opportunity for marginalised groups. These schools have a history in the United States dating back to before Arrupe's speech. In community-based research terms, such schools represent a particular application, which as demonstrated below is not without tension, of the insight that "that they have an institutional contribution to make in building sustainable communities in the broadest sense.... [This] work is with and not on communities" (Graham, 2014).

Drawing on that community engaged insight, the basic formula for nativity schools, first articulated and practiced by Jesuits working with immigrant groups in New York City in 1971, is to provide students from economically marginalised areas with extra support, including nutritious meals, longer schools days, and summer programming. This support is structures to be available throughout their whole school, post-secondary education, and early working careers. The term 'nativity' invokes images of caring and incarnation, in this case the coming alive of ideals of social justice and solidarity along the lines of Arrupe's articulation of menand-women-for-others. These schools are international in character in a much different way than a typical international school. The Mother Teresa Middle School in Regina and the Gonzaga Middle School in Winnipeg offer cases in point. This article now moves to discuss the former. 
A long time in planning, Mother Teresa Middle School celebrated its first graduating class in June 2014 (MTMS, 2016). Interestingly in terms of the subject matter of this article, the Mother Teresa Middle School employs an international assessment measure (a rare approach outside IB programs in Canada), and is part of the NativityMiguel Coalition (2016). With the addition of Mother Teresa Middle School, the latter networking group expended outside of the USA and became an international organization, which connects school communities that seek to employ Catholic (mainly Jesuit) education to empower students in marginalised urban areas. The school references this article's central concept in its articulation of its desired communityoriented character outcomes for alumni: “to create, 'Men and Women for Others' using Jesuit philosophies, models and teaching methods to graduate students who are: Loving, Religious, Intellectually Competent, Open to Growth and Committed to Doing Justice" (MTMS, 2016).

A tension remains here of seeking to turn 'the poor' into the elite by giving the best students exit points from marginalised communities. In the case of Mother Teresa Middle School, the majority of students at the school identify as Indigenous people. This can be a further point of tension in terms of a cogent instance of international identities (here as they interact within a particular nation-state) as Canada's settler society takes its first steps toward overcoming a deeply problematic and regrettable colonial past, with sources in a previous period of globalisation, by forging nation-to-nation relationships with Indigenous peoples. One horrific result of failures to build quality settler-Indigenous relationships, manifest in the area of education was the Indian Residential School system, which ran as a partnership with the Government of Canada and various wings of Christian denominations, including the involvement of the Jesuit order. The resultant educational institutions attempted to impose a Western uniformity on First Nation, Inuit, and Métis people (see Wotherspoon and Schissel, 2003). That attempt at the imposition of Western uniformity is both legitimately described as 'cultural genocide' and merited a multi-year truth and reconciliation commission (see TRC, 2015).

There are major social justice issues at play here. Applying an international development index to Indigenous peoples living in Canada as a cohort is illustrative of these issues. Shamefully, in terms of quality of life factors like access to safe drinking water, housing, rates, and life expectancy, Indigenous people score significantly lower than other Canadians do in international development-correlated demographic data. One symptom of this malaise is that Indigenous people have the poorest self-reported physical and mental health of all demographic groups in Canada (see $\mathrm{Na} \&$ Hample, 2016). A glocal heartfelt conscience, of the type pointed to by men-and-women-for-others, would view such inequalities as not only unjust but also untenable within (1) specific communities, and (2) Canadian and international society. Here is another link amongst a men-and-women-for-others identity, global ethics, and community engagement as discussed in the International Education Studies literature.

As demonstrated above, Go Forth and Teach is clear that such realities are of deepest concern to Jesuit education. Moreover, that document recommends engagement within the local context as essential to learning and links such engagement to a fruitful interchange of ideas amongst the global community of Jesuit educational institutions. For example, the document asserts, 
"the interchange of ideas will be more effective if each school is inserted into the concrete reality of the region in which it is located and is engaged in an ongoing exchange of ideas and experiences with other schools and educational works of the local church and of the country. The broader the interchange on the regional level, the more fruitful the interchange amongst Jesuit schools can be on an international level" (ICAJE, 1987, \#147). Within the Canadian Prairies context, in particular, addressing injustice in terms of settler-Indigenous relations as discussed above, clearly counts amongst the local concrete reality referenced here by the International Commission on the Apostolate of Jesuit Education. Given the order's former participation in multiple colonial projects in a previous world system, the resultant need for more supportive community engagement ought to count amongst the reasons for nativity schools to feature in a fruitful dialogue within international networks of Jesuit education institutions. With the right will and approach, that dialogue could easily extend to mainstream international education schools, colleges, and universities.

Considering further the concrete reality of the Canadian context as a settler society, in the cross-cultural sense, most schools in Canada, most especially in urban areas, are international. However, a sensitive cross-cultural approach to education is particularly significant in the case of the two nativity schools, located respectively in Regina and Winnipeg. This is especially true, when those schools community outreach successfully resonates with the goals associated with building nation-to-nation relationships between Indigenous peoples and settlers (cf. Williams, Tanaka, Leik \& Riecken, 2014). Here, with further study, there can emerge a number of insights that may be valuable to international education theory and practice in general.

Considering the above-discussed set of class, cultural, and nation-to-nation tensions brings us back to Mark Chipman, described as a man-for-others in the opening quotation of this article. Chipman is the Chairperson of the Board and one of the backers, along with several other alumni of the local Jesuit high school, of the new tuition-free nativity Gonzaga Middle School in the Point Douglas neighbourhood of Winnipeg, which welcomed its first class in September 2016. Like Regina, Winnipeg has a large urban Indigenous population. Too many members of that community live in poverty and experience the effects of racism and intergenerational trauma often resulting from colonial ventures like the Indian Residential School system. The Gonzaga Middle School has been careful to forge links with Indigenous leaders, including as board members and advisors, and to support Indigenous spiritual practices (GMS, 2016). Regardless, it has also proved controversial in the wake of the Indian Residential Schools' legacy, inclusive of the correlated inter-generational trauma. Even as it attempts to integrate the Truth and Reconciliation Commission of Canada's recommendations in all its programming, the spectre of a private Catholic school in area of the city with a large population of Indigenous people looms too large for some community activists (see Swan, 2016; cf. Israel, Schulz, Parker, Becker, Allen \& Guzman, 2008). Notwithstanding remaining tensions, due the outreach by Gonzaga school staff, there has been a transformation of the conflict revolving around identity in this regard. Board members and advisors have made a concerted effort to reach out to community-based activists, including Larry Morisette who was a co-founder of the well-known Children of the Earth High School, which celebrates Indigenous identities as 
one of its central focuses (see Meeches, 2006). Morisette initially voiced his opposition to a Catholic order re-engaging with Indigenous students but now supports the project. Facilitating this transformative dialogue are continuing, concrete, and community-engaged commitments including installing a permanent art exhibit in the school addressing the legacy of Indian Residential Schools in Canada and a pledge to support neighbourhood businesses, like the Neechi Commons Co-Operative, to cater feasts and functions (see CBC News Staff, 2016).

Issues of class are also relevant here, as the school will provide optional tuition-free access points to Catholic secondary schools in more affluent areas of the city, including the aforementioned Jesuit St. Paul's High School. Since the 1950s, St. Paul's has been located in the Tuxedo neighbourhood, which has the highest average and median incomes in the city (author correlating 2011 household survey data at City of Winnipeg Staff, 2016). Given its pertinence to this article's subject matter, it is important to note some key points projected toward its learning and large communities via the Gonzaga Middle school's mission statement. These points include a commitment to culturally sensitive education for students from lowincome families from urban core neighborhoods and a commitment to adapt the international framework of the NativityMiguel Coalition of Schools in order to meet local needs effectively. In this community-engaged light, the school asserts that it:

Will lower barriers to educational advancement and success through its strong academic program, longer school day, before and after school programming, extended school year (including summer camp weeks), enrichment activities, and mentoring and graduate support programs. The school will also provide a nutrition program (breakfast, lunch and two snacks), transportation to and from school, technology and other supports.

GMS seeks to develop 'men and women for others' while preparing students for success in high school and post-secondary study. It will strive to graduate students who are loving, intellectually competent, open to growth, spiritually alive and committed to doing justice.

GMS will support its students of all cultural and faith backgrounds in their growth toward becoming hopeful, confident, morally responsible leaders for love and service of their families and communities (GMS, 2016).

Notice here the invocation of language also found in the Mother Teresa Middle School statement, including men-and-women-for-others articulated as a learning outcome on the level of identity. This statement responds to international concerns not only in terms of the new-Canadian population, but also in the sense of nation-to-nation dynamics that properly come into play when Jesuit schooling seeks to build relationships with Indigenous families and communities. Here, Jesuit and mainstream international education practitioners can enter into a fruitful dialogue about culture, class, and international relationships.

Considering his example in conversation with the International Education Studies literature and principles of social justice and community engagement, the person of Mark Chipman 
is emblematic of some the tensions and promises that are active when a men-and-womenfor-others identity meets the realities of Jesuit education's location amongst both those with economic wealth and those living poverty. In not only the Winnipeg context but also in global terms, Chipman counts amongst the elite. He is a successful business owner and proprietor of an iconic sports franchise (the Winnipeg Jets) in an international league (the NHL), that ranks the dearest of all athletic ventures to the majority of Canadians. Chipman has amassed resources, including economic and cultural capital, which can make both local and global community-engaged impacts. That he turns to a group of concerned citizens, including some of his fellow alumni of a Jesuit school, and directs a portion of that capital towards seeking to address inequality in his home city is admirable compared to more self-referential alternatives. This statement rings true even as the education initiative he is supporting in a core neighbourhood is attracting controversy. The very existence of that controversy points to the need for trust building and community-based reconciliation of a type supported by the central concept of this article. Chipman's story points to how, in a cogent sense, a wellformed men-and-women-for-others identity may be a path to transform what could merely be 'old boys' networks into associations aiming for positive social change- a transformation that has already taken place in part. Yet, the partial nature of this transformation should not be underplayed. Indeed, the elitism active in an old boys culture also points to a real tension in both Jesuit and International Education's approaches to community-engaged learning, were, most especially outside of dedicated institutions like the nativity schools discussed above, there is a tendency to focus are serving the marginalized rather than learning from and with people living in poverty. In broad terms, as indicated above the spectre of elitism even haunts the nativity school model, wherein a concerted effort is made to value different knowledge sets, in combination with learning geared towards rather more mainstream definitions of success. Here, returning to this article's dialogue with the International Education Studies literature, Tristan Bunnell's (2010) discussion of the IB dynamics of a 'class-for-itself' are operative. These dynamics may be read as active within what Bunnell (2010) might label, in parallel with his discussion of an 'agenda for world peace' in the IB context, the 'irenic' Jesuit rhetoric of men-and-women-for-others. According to such a reading, the central concept of the present article may merely produce, at best, benevolent elite, who are business-oriented but sometimes socially responsible. Indeed, in all fairness, while there are many Jesuit alumni who are supportive of an agenda for substantive world peace, which would necessarily be inclusive of social justice and community engagement, others can easily be classified as supporting Bunnell's (2010) other category of more segmented 'agenda for world business'. The tension between internationalist and globalist identity remains active here.

From a perspective concerned with deep equality and solidarity, as pointed to by the concept of men-and-women-for-others and the aforementioned UWC (2016) values, it is important to take into account the realities of such mixed orientations present amongst graduates of both Jesuit educational institutions and international schools, colleges, and universities. However, properly activated, a men-and-women-for-others identity is itself a redeeming feature of Jesuit schools, colleges, and universities' alumni networks. For instance, if someone benefits 
during a hiring process because of a sought-out correlation between a diploma from a Jesuit educational institution and the host of values invoked by the hinge concept of this article, then that mode of advantaging emerges as a legitimate form of merit. In turn, such merit acts a redeeming feature of an elitist Jesuit old boys culture. Imagine here seeing a credential from a Jesuit school, college, or university on a CV and then reasonably trusting the person before them is likely to be a woman or man-for-others. When and where Jesuit education adequately heeds Arrupe's call to form men-and-women-for-others, the reasonableness of that scenario should follow. A similar point applies to the aforementioned UWC alumni networks. Here, emerges one tangible result of social justice oriented and community-engaged learning being integrated on the level of identity.

Further, in the former case, as Michael Holman (2014) highlights during his treatment of men-and-women-for-others: "Arrupe was not against students from our schools seeking to occupy positions of power and influence; but if they did, they should have been educated to use those positions to bring about change in favour of the poorest" (p. 142). In line with this reception of Arrupe's internationalist teaching, in contemporary Jesuit education, through programming like means-tested bursaries and, in particular, nativity schools, the transformation implied by invoking the concept of men-and-women-for-others is also now aimed at reaching further, helping to empower students from marginalised communities. International educational institutions that take seriously an imperative to support a truly global common good can learn from these developments. In these emerging models of Jesuit education, this is an empowerment not envisioned in solely economic terms. Rather, it is a concerted effort to empower students, in our last case from in and around the Point Douglas community in Winnipeg, to develop a host of virtues and attitudes, encompassed by the term men-andwomen-for-others. In this sense, Jesuit nativity school alumni do not earn unencumbered exit paths from marginalised communities through their educational experiences. Rather, they learn the skills to activate their potential as community-engaged agents. As a result, agency expands, so that it no longer only exists in elitist venues, which have characterised so much of the human geography of both Jesuit and international education (cf. Cambridge \& Thompson, 2004).

In so much as it accords with Arrupe's vision, and when integrated on the level of identity men-and-women-for-others, at its best, helps to set a series of transformative goals for students from marginalised communities. These goals are akin to the ones set for all students and alumni of the order's educational institutions since Arrupe's life-defining speech, which calls on all Jesuit-educated people to employ their agency and take up their potential to be contemplatives in action for positive social change. Taking up that call or working towards incarnating similar values, as appropriately articulated in mainstream international education contexts like the UWC (cf. Bunnel, 2010), can help build healthy communities and quality glocal relationships. In this manner, learning that activates the full and tangible potential of all that is invoked by the concept of men-and-women-for-others within Jesuit education as it might inform, and be informed by, the praxis of international education can positively contribute to international transformation. 


\section{Conclusion}

This article has engaged in a conversation on the level of theory and practice between Jesuit and international education as they related to identity formation. Several of the confluences and divergences mapped above showed a particular concern for education that is communityengaged, solidarity-oriented, and otherwise supportive of a glocal ethic. The challenge now is to move forward with actual collaborations, so that diverse constituencies, inclusive of internationalist and Jesuit educational communities in particular, can come together, despite different motivations for doing so, to work on specific community-engaged projects in the service of social justice and a creative common good.

The relevant challenge for both Jesuit and international education is how to ensure that pulls towards corporate globalist orientations do not submerge a fuller meaning of integrated identities like men-and-women-for-others in their wake. The tension here is real. It is related to the expectations of certain fee paying parents, whose definitions of success may be more concerned with monetary wealth than building a strong, equal society characterized by community-engagement across diverse identity markers. The above discussion of the adaptability of IB norms to for profit schools is a case in point. However, theses tensions are also present at Jesuit educational institutions in different forms. Setting educational outcome goals on the level of identity formation calls students and alumni back towards community engagement and other work to establish fuller conditions of social justice across multiple societies. In this manner, and others surveyed above, it thus provides an important moral yardstick, a measure that invokes the dangerous memory of the Ignatian and internationalist ideals against which contemporary Jesuit and international education are appropriately measured.

A question remains about how serious of a hold such a moral measure has in both Jesuit and international educational institutions in the face of globalist and self-interested segmentation that too often characterizes the current world system. From a community-engaged perspective, this question must not go unaddressed. Otherwise, neglect will only serve an unjust status quo. Men-and-women-for-others undertaking CSL for and with diverse communities is medicine to inoculate against manifestations of globalist ethics that work against much needed transformative, empowering, and cooperative social change. Ensuring that concepts like menand-women-for-others, in both their Jesuit and internationalist strains, are both 'caught and taught' in this integrative sense thus emerges a cogent task for the educational project as it seeks to meet contemporary challenges to the benefit of social justice and a creative common good.

\section{Acknowledgments}

The author would like to thank Mary Hayden (in particular), Tristan Bunnell, and the anonymous reviewers for their feedback, which greatly improved this article. 


\section{About the Author}

Christopher Hrynkow, PhD, ThD is an associate professor in the Department of Religion and Culture at St. Thomas More College, University of Saskatchewan. Email: chrynkow@ stmcollege.ca

\section{References}

Alonso, A. (1961). Catholic action and the laity. St. Louis, USA: B Herder Book Co.

Arrupe, P. (1973). Men for others; Men and women for others. Retrieved from http://online ministries.creighton.edu/CollaborativeMinistry/men-for-others.html.

Bai, H., Cohen, A. \& Rabi, S. (2014). Post-individualist pedagogy: Relationship as teaching. In F. Deer, T. Falkenberg, B. McMillan \& L. Sims (Eds). Education for sustainable well-being: Concepts, issues, perspectives, and practices (pp. 23-36). Winnipeg, Canada: Education for Sustainable WellBeing Press.

Barre, N. (2001). History of the Jesuit workers' mission. Promotio Iustitae 75, 49-53.

Barry, W.A. \& Doherty, R.G. (2002). Contemplatives in action: The Jesuit way. Mahwah: Paulist Press.

Bates, R. (2012). Is global citizenship possible, and can international school provide it? Journal of Research in International Education 11(3), 262-274.

Bernie, C.J. (2013). Jesuit education and social change in El Salvador. New York, USA: Routledge.

Boland, R. (2011). Living abroad in Hong Kong. Berkeley, USA: Perseus Books.

Brown, P., Lauder, H. \& Aston, D. (2010). The global auction: The broken promises of education, jobs, and incomes. Oxford, England: Oxford University Press.

Bunnell, T. (2010). The International Baccalaureate and a framework for class consciousness: the potential outcomes of a 'class-for-itself'. Discourse: Studies in the Cultural Politics of Education 31(3), 351-362.

Cambridge, J. \& Thompson, J. (2004). Internationalism and globalization as contexts for international education. Compare: A Journal of Comparative and International Education 34(2), 161-175.

Canadian Jesuits International. (2016). Who we are. Retrieved from http://www. canadianjesuitsinternational.ca/ who-we-are/who-we-are/.

CBC News Staff. (2016). Gonzaga Jesuit school wins over some critics, but not all, as it prepares to open in Winnipeg: Private middle school in Point Douglas will open with first Grade 6 class this fall. Retrieved from http://www.cbc.ca/news/canada/manitoba/gonzaga-jesuit-schoolwinnipeg-1.3636096.

City of Winnipeg Staff. (2016). 2011 Census: City of Winnipeg neighbourhood profiles. Retrieved from http://winnipeg.ca/census/2011/.

Consolmagno, G. (2014). Galileo: Science, faith, and the Catholic Church. Chicago: Now You Know Media.

Christensen, M.Z. (2013). Nabua and Maya Catholicisms: Texts and religion in colonial Mexico. Berkeley and Stanford: American Academy of Franciscan History and Stanford University Press.

Council of International Schools (CIS). (2015). Code of ethics for higher education. Retrieved from http://www.cois.org/page.cfm?p=2019. 
Currie, C.L. (1999). Greetings. In M.R. Tripole (Ed). Jesuit education 21: Conference proceedings on the future of Jesuit higher education (pp. 3-7). Philadelphia, USA: St. Joseph's University Press.

Davies, I. (2003). Developing education for citizenship. In A. Lockyer, B. Crick \& J. Annette (Eds). Education for democratic citizenship: Issues of theory and practice (pp. 161-174). Aldershot, England: Ashgate.

Educate Magis Staff (2016). Educate magis: Collaborating, empowering, transforming; current map: Locate and learn more about Jesuit and Ignatian schools around the world. Retrieved from https:/ /www. educatemagis.org/current-map/.

Ganns, G. (1956). Saint Ignatius' idea of a Jesuit university. Milwaukee, USA: The Marquette University Press.

Garcia, J.I. \& Sendin, P. (2015). Networking globally for justice. Retrieved from http://www. ecojesuit.com/networking-globally-for-justice/8800/.

Gaventa, J. (1993). The powerful, the powerless, and the experts: Knowledge struggles in an information age. In P. Park, M. Brydon-Miller, \& B. Hall (Eds.). Voices of change: Participatory research in the United States and Canada (pp. 21-40). Westport, USA: Bergin \& Garvey.

Girard, R. (2003). The mimetic theory of religion: An outline. In P. Gifford (Ed). 2000 years and beyond: Faith identity and the 'common era' (pp. 88-105). London, England: Routledge.

Gellar, C.A. (1993). How international are we? International Schools Journal 26, 5-7.

Gerlicz, T. \& Stavarz, L. (2011). Service learning at the American school of Warsaw. Retrieved from https://www.ceesa.org/phocadownload/servicelearning/part_2_ casestudies_ intlschools/9Poland/1WarsawCaseStudy.pdf.

Global Education Management Systems (GEMS). (2016). Core values: Part of our DNA for 55 years. Retrieved from http://www.gemseducation.com/why-a-gems-education/core-values/.

Gnass, G.E. (1991). Ignatius of Loyola: Spiritual exercises and selected works. New York, USA: Paulist Press.

Gonzaga Middle School (GMS). (2016). About us. Retrieved from http://www.gonzagamiddleschool. ca/about-us.

Graham, K.A.H. (2014). Beyond all in the family: Community-based research in Canada. Academic Matters: OCUFA's Journal of Education (June). Retrieved from http://www. academicmatters. ca/2014/06/beyond-all-in-the-family-community-based-research-in-canada/.

Hall, B.L., Escrigas, C., Tandon, R. \& Grandos Sanchez, J. (2014). Transformative knowledge to drive social change: Visions for the future. In C. Escrigas, G. Sanchez, B. Hall, R. Tandon, G.

Puig \& M. Forns (Eds.). Higher education in the world 5: Knowledge engagement and higher education, contributing to social change. GUNi Series on the Social Commitment of Universities. (pp. 301310). Hampshire, UK: Palgrave Macmillan.

Halstead, J.M \& Taylor, M.J. (2000). Learning and teaching about values: A review of recent research. Cambridge Journal of Education 30 (2), 169-202.

Hayden, M. \& Thompson, J.J. (2008). International schools: Growth and influence. Paris, France: United Nations Educational, Scientific and Cultural Organization.

Hill, I. (2012). Evolution of education for international mindedness. Journal of Research in International Education 11 (3), 245-261.

Holman, M. (2014). Father Pedro Arrupe and Jesuit education: A personal reflection. International Studies in Catholic Education 6(2), 140-147.

International Baccalaureate Organization (IBO). (2013). IB learner profile. Retrieved from http:// www.ibo.org/globalassets/digital-tookit/flyers-and-artworks/learner-profile-en.pdf. 
International Baccalaureate Organization (IBO). (2014). Programme standards and practices. Retrieved from http://ibo.org/globalassets/publications/become-an-ibschool/ programmestandardsandpractices.pdf.

International Commission on the Apostolate of Jesuit Education (ICAJE). (1987). Go forth and teach: The characteristics of Jesuit education. Washington, USA: Jesuit Secondary Education Association.

Israel, B, Schulz, A.J., Parker, E.A., Becker, A.B., Allen III, A.J. \& Guzman, J.R. (2008). Critical issues in developing and following community-based participatory research principles. In M.

Minkler \& N. Wallerstein (Eds). Community-based participatory research for health: From Process to Outtomes. (pp. 47-66). San Francisco, USA: Jossey-Bass.

Jesuit Commons: Higher Education at the Margins (JC:HEM). (2016). About us. Retrieved from http://www.jc-hem.org/about-us/.

John XXIII. (1961). Mater et Magistra. Retrieved from http://w2.vatican.va/content/john-xxiii/en/ encyclicals/documents/hf_j-xxiii_enc_15051961_mater.html.

Kavanaugh, J.F. (1989). Jesuit education and social justice in theory and practice. In R.E. Bonachea (Ed). Jesuit higher education: Essays on an American tradition of excellence (pp. 168-176). Pittsburgh, USA: Duquesne University Press.

Kolvenbach, P.H. (2008). The service of faith and the promotion of justice in American Jesuit higher education. In G.W. Traub (Ed). A Jesuit education reader (pp.144-162). Chicago, USA: Loyola Press

Kubow, P., Grossman, D. \& Ninomiya, A. (2000). Multidimensional citizenship: Educational policy for the $21^{\text {st }}$ century. In J. Cogan \& R. Derricott (Eds). Citizenship for the $21^{\text {st }}$ century: An international perspective on education (pp. 131-150). London, UK: Kogan Page Limited.

Madelin, H. (1991). A man for others. America 164(6), 166-172, 188.

McFarland, M. (2014). Comment. Quoted in S. Ogunyemi. Malawi: A ticket to hope, graduation of online university students in Dzaleka refugee camp. Retrieved from http://en.jrs.net/ newsdetail?'TN=news-20141021093827\#sthash.Jm0eLkpP.dpuf.

Meeches, L. (2006). Children of the Earth School. Winnipeg, Canada: Aboriginal Peoples Television Network and Meeches Video Productions.

Mestenhauser, J.A. (2002). In search of a comprehensive approach to international education: A systems perspective. In W. Grunzweig \& N. Rinehart (Eds). Rockin' in Red Square: Critical approaches to international education in the age of cyberculture (pp. 165-202). Muenster, Germany: Lit Verlag.

Metz, R.E. (1995). Ignatius knew. Washington: Jesuit Secondary Education Association.

Mitchell, R.A. (2008). Five traits of Jesuit education. In G.W. Traub(Ed). A Jesuit education reader (pp. 111-112). Chicago, USA: Loyola Press.

Modras, R. (2004). Ignatian humanism: A dynamic spirituality for the $21^{\text {st }}$ century. Chicago: Loyola Press.

Mother Teresa Middle School (MTMS). (2016). Mission. Retrieved from http://mtms choolregina. com/about-us/mission.

Na, L. \& D. Hample. (2016). Psychological pathways from social integration to health: An examination of different demographic groups in Canada. Social Science \& Medicine 151, 196205.

Nativity Miguel Coalition. (2016). Mission. Retrieved from https://nativitymigueldotorg. wordpress. com/about/. 
O'Hare, J.A. (1999). What are the odds of Jesuit higher education surviving in America. In M.R. Tripole (Ed). Jesuit education 21: Conference proceedings on the future of Jesuit bigher education (pp. 433-443). Philadelphia, USA: St. Joseph’s University Press.

O’Malley, J.W. (2000). How the first Jesuits became involved in education. In V.J. Duminuco (Ed). The Jesuit ratio studiorum: 400th anniversary perspectives (pp. 56-74). New York, USA: Fordham University Press.

O’Malley, J.W. (1993). The first Jesuits. Cambridge, USA: Harvard University Press.

O'Keefe, J. M. (2011). Global Partnerships in Jesuit Higher Education. Journal of Catholic Education 14(3), 333-337.

Ochocka, J. \& Janzen, R. (2014). Breathing life into theory. Illustrations of community-based research: Hallmarks, functions and phases. Gateways: International Journal of Community Research and Engagement 7, 18-33.

Pagberg, J. (1991). "To speak, perchance to dream": The conversations of a college. Regina: Campion College.

Parker, G. (1998). The grand strategy of Philip II. New Haven, USA: Yale University Press.

Perry, J. (2015). St. Paul's College in the new millennium. In C. Butterill (Ed). St. Paul's College: Facing the new millennium (pp. 56-60). Manitoba, Canada: St. Paul's College.

Phillips, D. and Schweisfurth, M. (2008). Comparative and international education: An introduction to theory, method, and practice. London, England: Continuum International Publishing Group.

Rashford, N. (1999). Greetings. In M.R. Tripole (Ed). Jesuit education 21: Conference proceedings on the future of Jesuit higher education (p. 2). Philadelphia, USA: St. Joseph's University Press.

Scaglione, A. (1986). The liberal arts and the Jesuit colleges. Amsterdam: John Benjamins Publishing Company.

Segundo, J. L. (1976). Liberation of theology. Maryknoll, USA: Orbis Books.

Swan, M. (2016). Activists compare Winnipeg School to residential schools. Prairie Messenger, February $10,4$.

Sobrino, J. (1991). Awakening from the sleep of inhumanity. Christian Century 3 (April), 364-370.

Spilker, R., Nagel, R., Robinson, J., Brown, L., \& Tremblay, C. (2016). Creating citizen communities? Innovation and impacts in community university engagement networks. Institute for Studies and Innovation on Community-University Engagement, University of Victoria, British Columbia, Canada. Retrieved from https://www.uvic.ca/research/centres /cue/assets/ docs/NetworkStudy.pdf.

Synod of Bishops. (1971). Justice in the world. Vatican. Retrieved from http://www.shc.edu/ theolibrary/resources/synodjw.htm.

The Economist Staff. (2014). The new local; international schools. The Economist, 413, Dec 20), 88. Retrieved from http://cyber.usask.ca/login?url=http://search.proquest.com/docview/ 1638915239 ? accountid $=14739$.

Therborn, G. (2000). Globalizations dimensions, historical waves, regional effects, normative governance. International Sociology 15(2), 151-179.

The Truth and Reconciliation Commission of Canada (TRC). (2015). Honouring the truth, reconciling for the future: Summary of the final report of the truth and reconciliation commission of Canada. Retrieved from http://www.trc.ca/websites/trcinstitution/File/2015/Findings/Exec_ Summary_2015_05_31_web_o.pdf. 
Thompson, J.J. (1998). Towards a model for international education. In M.C. Hayden \& J.J.

Thompson (Eds). International education principles and practices (pp. 276-290). London: Kogan Page.

Tsumagari, M.I. (2010). The enduring effects of a United World College education as seen through a graduate's eyes. Journal of Research in International Education 9 (3), 289-305.

United World Colleges (UWC). (2016). Missions and values. Retrieved from https://uwc.org about/ missions-values.

Urkudi, L. (2010). A glocal environmental movement against gold mining: Pascua-Lama in Chile. Ecological Economics 70 (2), 219-227.

Vallaeys, F. (2014). University social responsibility: A mature and responsible definition. In C. Escrigas, J. Granados Sanchez, Budd L. Hall, R. Tandon, G. Puig \& M. Forns (Eds.). Higher education in the world 5: Knowledge engagement and higher education, contributing to social change. GUNi Series on the Social Commitment of Universities. (pp. 88-96). Hampshire, UK : Palgrave Macmillan.

Walsh, P. (2000). New wine in renewed wineskins: A Jesuit school now. In J. Cairns, R.Gardner \& D. Lawton (Eds). Values and the curriculum. (pp. 134-149). Portland, USA: Woburn Press.

Wiecek, P. (2016). Hockey school. Winnipeg Free Press, January 29, C1.

Williams, L., M. Tanaka, V. Leik \& T. Riecken. (2014). In C.Etmanski, B. Hall \& T. Dawson (Eds.). Learning and teaching community-based research: Linking pedagogy to practice. (pp. 229-252). Toronto, Canada: University of Toronto Press.

Wotherspoon, T. and Schissel, B. (2003). The legacy of school for Aboriginal people: Education, oppression, and emancipation. Don Mills, Canada: Oxford University Press. 